\title{
REGULATION OF ORDINARY PARTNERSHIP UNDER ETHIOPIAN LAW: A COMPARATIVE ANALYSIS OF SELECTED LEGAL ISSUES WITH THE FRENCH CIVIL PARTNERSHIP AND THE THAI ORDINARY PARTNERSHIP REGIMES
}

\begin{abstract}
Civil/ordinary partnerships as non-commercial entities play a vital role as an alternative form of doing business in various jurisdictions. Though the issue of where they should be regulated is becoming nonsensical in recent times, it is wise to have a well-structured legal framework which regulates these entities. This article aims to conduct a comparative analysis of the regulation of Ethiopia's ordinary partnership with the French civil code partnership and the Thai ordinary partnership only on issues of formation, transfer of share, management, liability of partners, dissolution of partnership, distribution of profit and loss, and expulsion of a partner. The comparative analysis shows that in many areas of regulation, the Ethiopian law has more commonalities with that of Thai ordinary partnership and French civil code partnership legal regimes. This article also finds that the Ethiopian law of ordinary partnership ought to be improved as regards the issues of the transfer of shares related to ascendants and descendants, on the distribution of profits and losses, on the role of partners in a dissolution of the partnership, and on the expulsion of a partner.
\end{abstract}

* LL.B (Bahir Dar University), LL.M in Business and Corporate Law (Bahir Dar University), Lecturer in Law, College of Law, Debre Berhan University, the author can be reached at: email: haileyesus1983@gmail.com or israkidan@gmail.com, ORCID: https:// orcid.org/ 0000-0002-5665-0956. 


\section{Keywords}

Ordinary partnership regulation - civil code partnership - management - expulsion transfer of share - comparative law

\section{INTRODUCTION}

Generally, a person who wants to engage in business can do so in the form of a sole proprietorship or by forming a partnership or company with others. A Partnership is preferable for a business ty pe that requires a limited number of members and capital. In this regard, the Ethiopian Commercial Code recognizes six types of business organizations specifically, (i) general partnership, (ii) limited partnership, (iii) ordinary partnership, (iv) joint venture, (v) share companies, and (vi) private limited companies. ${ }^{1}$ These six types of business organizations are categorized into commercial and non-commercial, depending on the form and object of their engagement.

Concerning the form of business organizations, share companies and private limited companies are always commercial regardless of their object of engagement. On the other hand, an ordinary partnership is always non-commercial. ${ }^{2}$ The remaining three forms of business organizations (joint venture, general partnership, and limited partnership) can be either commercial or non-commercial depending on the type of activities in which they are engaged. ${ }^{3}$ Under Ethiopian law, an ordinary partnership is recognized as a non-commercial corporation regardless of its object of engagement. It is quite similar to what is adopted by the 1996 French Companies Law. ${ }^{4}$ Under this law, it is provided that the form which the company adopts is considered as the criterion for its nature regardless of the types of work it is engaged on. ${ }^{5}$

\footnotetext{
1 Commercial Code of the Empire of Ethiopia of 1960, Negaret Gazeta, Extraordinary Issue 19-year No.3 book II, article 212 (1).

${ }^{2}$ Id., article 10 and 213(1).

${ }^{3}$ Ibid.

4 Sayed M. Hosni, "Commercial and Civil Companies in UAE Law", Arab Law Quarterly, Vol. 7, No. 3 (1992), pp. 162.

${ }^{5}$ Ibid.
} 
Although there is difference across jurisdictions, generally, in the civil law legal system, non-commercial corporations are regulated under the Civil Code. ${ }^{6}$ However, Ethiopia is different from other countries that follow the civil law legal system in that an ordinary partnership is regulated under the Commercial Code, not the Civil Code.

The Attorney General of Ethiopia is currently leading a revision of the 1960 Commercial Code of Ethiopia. There is pressure from the legal community to revise part of the code governing ordinary partnership. However, there are concerns about how and by whom ordinary partnerships should be regulated. The drafting committee suggests that ordinary partnerships should not be included in the commercial code and instead should be regulated under the Ethiopian non-profit organization laws. However, the detail of the regulatory issues concerning the ordinary partnership needs the attention of the revision committee as well. This article is intended to establish issues related to the regulation of ordinary partnerships and to suggest the best experiences that could help in addressing the legal issues concerning ordinary partnerships in Ethiopia.

This paper aims to make a comparative analysis of the regulation of Ethiopia's ordinary partnership as a non-commercial corporation with other jurisdictions' non-commercial partnerships. This analysis compares Ethiopia's ordinary partnership with the French civil code partnership (société civile) law and the Thai ordinary partnership law. In this regard, the writer consults the German experience (Gesellschaft bürgerlichen Rechts, GbR) occasionally when it is unique and important.

The justification for selecting the French civil code partnership legal regime is that the Ethiopian laws that govern partnerships and other corporations are transplanted from the French legal system. Additionally, the French civil code is also the pioneer in having a well-regulated legal regime of non-commercial partnership in a codified form. The justification for selecting the Thai ordinary partnership regime is the fact that Thailand is one of the civil law countries which regulate both commercial and non-commercial corporations under a single code called in the Thailand Civil and Commercial Code. Additionally, Thailand's legal system is highly influenced by the French legal system, and it is the

\footnotetext{
${ }^{6}$ Italian, Swiss, French and Germany legal systems, UAE Civil companies.
} 
second country after Ethiopia to use the term 'ordinary partnership' to refer to the commonly known non-commercial partnership and to appreciate why.

The scope of comparison is limited only to selected issues associated with the regulation of civil/ordinary partnerships, which include the formation of the partnership, transfer of share, management of the partnership, liability of partners, distribution of profit and loss, dissolution of partnership, and expulsion of a partner. The reason for this limiting is mainly to avoid being overambitious in terms of scope. It is not possible to cover all the aspects of ordinary partnership law across the jurisdictions in comparison. The writer, after reading the relevant literature on Ethiopian ordinary partnership law and identifying key problems associated with it, decided to limit the discussion to these issues rather than go into details.

\section{Definition AND NATURE}

Traditionally, ordinary partnerships used to be divided into three; universal, general, and particular partnerships. As a result, it is hard to find a common nomenclature, nature, and definition for this type of business organization across all jurisdictions. For instance, a universal partnership is an ordinary partnership in which all the property and services of the partners are united and all the profits they generate are for their joint benefit. ${ }^{7}$ A general partnership is one which is created for the purposes of some general kind of business, whereas a particular partnership is one created for a single transaction or venture. ${ }^{8}$

Coming to the comparison of the jurisdictions in Ethiopia's and Thailand's legal systems, non-commercial partnership is named as ordinary partnership whereas, in the German and French laws, it is named as civil code partnership. However, under all legal systems except the Thai civil and commercial code, there is no direct definition of the respective

7 Mechem, Floyd R., Elements of the Law of Partnership., Chicago: Callaghan \& Company, 1896, p.13.

${ }^{8}$ Ibid. 
civil code partnership or ordinary partnership. The Ethiopian ${ }^{9}$ and the French civil code ${ }^{10}$ tried to define it by employing a negative definition that it is any business organization that does not properly conform to the rest of the forms of business organizations. Similarly, the German Civil Code indirectly tried to define it as a partnership of persons in pursuit of a common purpose. ${ }^{11}$ Coming to the Thai ordinary partnership, it provides a direct definition and defines it as a kind of partnership in which all the partners are jointly and severally liable for all the obligations of the partnership. ${ }^{12}$

Regarding the nature of this corporate structure, in German law, civil code partnership is one of the practically important corporate structures when no trading activity proper is pursued. It is mainly used in the liberal professions for the joint exercise of free professions.$^{13}$ It is also used in other cases, for example in consortium operations. ${ }^{14}$ Correspondingly, in Thailand, this partnership has a non-commercial nature and is limited to certain regulated professions, such as medical personnel, lawyers, certain types of experts such as agricultural and forestry professionals providing a consultancy service, commissaries aux competes, and industrial property consultants. The case in France is also similar; as société civile is used for alternative forms of doing business in the construction industry (real estate) and professional services like the medical service. ${ }^{15}$ The Ethiopian law provides that an ordinary partnership can carry out any other economic activities except those economic activities which are listed in Article 5 of the Commercial Code. It

9 Commercial Code of Ethiopia, supra note 1, article 227.

${ }^{10}$ Text of the Code in English available at: https://www.fd.ulisboa.pt/wp-content/ uploads/2014/12/Codigo-Civil-Frances-French-Civil-Code-english-version.pdf[last accessed 2.9. 2020].

11 Warth \& Klein Grant Thornton AG., Doing Business in Germany, available at: https:// www.grantthornton.lt/globalassets/1.-member-firms/lithuania/pdf/doing-business-ingermany-2017.pdf [last accessed 10.3.2021].

12 The Civil and Commercial Code of Thailand, Section 1025, available at: <https://www. samuiforsale.com/law-texts/thailand-civil-code-part-1.html> [last accessed 10.3.2021].

13 Andenas, Mads \& Wooldridge, Frank, European Comparative Company Law, Cambridge Books, Cambridge University Press, 2012, p. 131.

${ }^{14}$ Ibid.

15 "Doing Business in France," Business France, available at https://world.businessfrance.fr/middle-east/wp-content/uploads/sites/906/2020/10/Establishing-a-Businessin-France-Booklet-1-2017-edition.pdf [last accessed 10.12.2020]. 
is quite similar to the Louisiana Ordinary partnership..$^{16}$ The list of economic activities as described in Article 5 is exhaustive and the types of economic activities which an ordinary partnership may carry out are unlimited. ${ }^{17}$

\section{FORMATION}

In all of the four jurisdictions including the German Civil law partnership, both civil code partnerships and ordinary partnerships are formed by the conclusion of a partnership agreement. ${ }^{18}$ In the French civil code partnership ${ }^{19}$ and the Ethiopian ordinary partnership ${ }^{20}$ registration is also a formation requirement. The case in Thailand is somewhat different: the registration requirement is not always mandatory; it is only required when that partnership wants to be registered. ${ }^{21}$ However, German law does not require civil law partnerships to be registered. As a result, a civil law partnership does not have a legal personality. It is simply an aggregate of persons rather than having a unified trade name. However, in 2001, the Federal Supreme Court of Germany gave a landmark decision. ${ }^{22}$ This decision gave legal personality to the civil law partnership. Nevertheless, still there are cases in which it lacks

${ }^{16}$ F. Hodge O'Neal, "An Appraisal of the Louisiana Law of Partnership: A Comparative Focus on Source Materials and Underlying Practices (Part II)", Louisiana Law Review, Vol. 9 No. 3 (1949), pp. 473-474.

17 Alemayehu Fentaw and Kefene Gurmu, Law of Traders and Business Organizations: A Course Material, (sponsored by Justice and Legal Systems Research Institute, Unpublished, Addis Ababa, Ethiopia, January 2008), p. 56.

${ }^{18}$ German Civil Code in the version promulgated on 2 January 2002 (Federal Law Gazette [Bundesgesetzblatt] I p. 42, 2909; 2003 I p. 738), last amended by Article 2 (16) of the statute of 19 February 2007 (Federal Law Gazette [Bundesgesetzblatt] I p. 122), Section 705, available at https://www.gesetze-im-internet.de/englisch_bgb/englisch_bgb. html [last accessed 15.11.2020], Commercial Code of Ethiopia, article 210 (1) and 212(1) (a) and Civil Code of France, supra note 10, Article 1835.

19 Civil Code of France, supra note 10, Article 1842.

${ }^{20}$ Commercial Code of Ethiopia, supra note 1, Article 222.

21 "Establishing a Business Entity in Thailand," ILN Corporate Group, available at: https://www.dejudomlaw.com/wp-content/uploads/2014/12/Establishing-a-BusinessEntity-In-Thailand-Fall-2014.pdf [last accessed 12.2.2021].

${ }^{22}$ Andenas, Mads \& Wooldridge, Frank, supra note 13, p.132 
legal personality, when the civil law partnership does not carry out any external activity. ${ }^{23}$

Coming to the case of the amount of contribution and capital requirement, in all three jurisdictions, it is presumed that there is equal contribution unless otherwise agreed.$^{24}$ Regarding the type of contribution, in the case of the French, Ethiopian, and Thai ordinary/civil Partnership, money, property, the use of property, debt, as well as skill can be contributed. ${ }^{25}$ However, in the German Civil Code partnership, neither debt nor skill may be contributed. ${ }^{26}$ The fate of the partner who fails to deliver his contribution is not regulated under the German and Ethiopian legal systems. This issue is regulated under Thai law and it provides that, if someone fails to deliver his contribution, written notice must be given to him by registered letter to deliver it within a reasonable time. ${ }^{27}$ If he fails to do so again, then he may be excluded from the partnership by a decision of all the other partners, or of such a majority as is provided in their agreement. ${ }^{28}$

\section{TRANSFER OF SHARE}

Generally, in the case of partnership, unlike corporate shareholders who may sell their shares of stock without restriction, a partner's share in the partnership is not freely transferable. ${ }^{29}$ In the case of French Civil Code partnership, as a principle the transfer of shares is possible either to a partner or a third party with the approval of all partners. However, the law provides exceptions. The first exception is that it is possible to agree under their articles of association for the approval of the transfer

${ }^{23}$ Ibid.

${ }^{24}$ Commercial Code of Ethiopia, supra note 1, Article 229(3); Civil Code of Germany, supra note 18, article 706(1); Civil and Commercial Code of Thailand, supra note 12, Section 1027, Civil Code of France, supra note 10, Article 1845-1.

${ }^{25}$ Commercial Code of Ethiopia, supra note 1, Article 229 (1) and (2); Civil and Commercial Code of Thailand, supra note 12, Section 1026;

${ }^{26}$ Civil Code of Germany, supra note 18, Article 706.

${ }^{27}$ Civil and Commercial Code of Thailand Supra note 12, Section 1031.

${ }^{28}$ Ibid.

${ }^{29}$ Schneeman, A., The Law of Corporations and other Business Organizations, Clifton Park, New York: Delmar Cengage Learning, 2010, pp. 76. 
by the majority which the partners may fix, or which may be decided on by the managers. The second exception is on the transfer of shares made to ascendants and descendants. The law provides that if someone wants to transfer his shares to ascendants or descendants there is no need to give approval. ${ }^{30}$ The law also addresses other issues related to the transfer of share. For instance, the leaving partner is obliged to give advance notice about the planned transfer. ${ }^{31}$ Besides, it regulates the fate of the transfer when several partners express their interest in acquiring the share and when there is no partner who stands to acquire the share. ${ }^{32}$ The case in Ethiopian ${ }^{33}$ and Thai ${ }^{34}$ law is somewhat different. Though it is possible to introduce a third party as a partner with the consent of all the partners, neither of the laws provides an exception to this rule. Besides, there is no provision that regulates the advance notice requirement and other issues directly related to the transfer of shares. The position taken by the French law appears to be better. Although the nature of partnership requires strict regulation of the withdrawal and coming in of a partner, it should not be absolute; at least there should be an exception for ascendants and descendants of the partners.

\section{MANAGEMENT}

In every business organization and association, the very important issue that needs to be regulated is the issue of who manages the entity. The operational management of a partnership includes two separate legal steps in dealings with third parties. ${ }^{35}$ The first is the internal process of making decisions for the partnership. ${ }^{36}$ The second is the process of

30 Civil Code of France, supra note 10, article 1861.

${ }^{31}$ Ibid.

${ }^{32}$ Ibid., Article 1862.

${ }^{33}$ Commercial Code of Ethiopia, supra note 1, Article 250.

${ }^{34}$ Civil and Commercial Code of Thailand, supra note 12, section 1040 and 1041.

${ }^{35}$ Cahn, A., \& Donald, D., Comparative Company Law: Text and Cases on the Laws Governing Corporations in Germany, the UK and the USA, Cambridge: Cambridge University Press, (2018), p.27.

${ }^{36}$ Ibid. 
carrying out these decisions vis-à-vis third parties; that is about representation of the partnership before third parties. ${ }^{37}$

Coming to the comparison of jurisdictions, civil partnership under the French law is managed by one or several persons whether they are partners or not, who are appointed either by the articles of partnership, or by a special act, or by a resolution of the partners. ${ }^{38}$ The same position is taken by Ethiopia, where the commercial code provides that all partners shall have a right to act as managers unless the partnership agreement or a decision of the partnership has appointed one or more partners or a third party to be a manager. ${ }^{39}$ Under both the Ethiopian and French laws, there is room for a third party to be a manager of the partnership, though joint management of partners is presumed. Under both laws, partners by agreement can appoint a non-partner professional manager as manager of the business.

In Thailand, it is not clear whether a third party can be a manager or not. Rather, the law provides only that if there is no agreement between the partners as to the management of the business of the partnership, each of the partners shall become the manager of the business. ${ }^{40}$ Is there a possibility of appointing a third party as a manager? Literally from the reading of the law, it seems that what is required is agreement of the partners. The writer of this article believes that if the Thai lawmaker intends to open it for a third party, it may provide explicitly as in the French and Ethiopian laws.

To conclude, the approach taken in the management of ordinary partnership in the Ethiopian law is similar to the French civil code partnership, but slightly different from that of the Thai ordinary partnership. The approach of Ethiopian and French law can be taken as the best approach, mainly because, unlike Thai law, the Ethiopian and French laws allow the partners to appoint a professional manager outside the members.

\footnotetext{
37 Ibid.

38 Civil Code of France, supra note 10, Article 1846.

39 Commercial Code of Ethiopia, supra note 1, Article 236.

40 Civil and Commercial Code of Thailand, supra note 12, Section 1033.
} 


\section{LIABILITY OF PARTNERS}

Both in Ethiopia ${ }^{41}$ and in Thailand, ${ }^{42}$ partners of an ordinary partnership are jointly, severally, and unlimitedly liable for the acts of the partnership. A partner's liability is not limited by the amount of his contribution to the partnership capital, but rather extends to his entire property. It makes no difference what may be his share or interest in the partnership business. It does not matter whether he is an actively engaging or passive partner.

Being jointly and severally liable is regarded as the main feature of ordinary partnership in both the common law and civil law legal systems. ${ }^{43}$ In the case of the French Civil Code partnership, the partners of civil code partnerships do not carry joint and several liabilities for the obligations of the partnership. They will be liable only proportionally to their share in the partnership. ${ }^{44}$ Besides, the law also adopts the principle of benefit of discussion, $\mathrm{s}$ it provides that creditors may sue a partner for payment of the debts of the partnership only after having first sued the partnership as an entity. ${ }^{45}$

To conclude, the position taken by the Ethiopian and Thai laws is very impressive in the light of the very nature and purpose of the ordinary/civil code partnership; as it stands to create a relationship in which each partner is understood as an agent for the other partners. Besides, making partners jointly and severally liable for the acts done while they are partners is sound in the light of the interest of third parties and sustainability of the partnership, whereas coming to the French law, exemption of partners from being severally liable would not be fair and justified.

${ }^{41}$ Ibid., Article 255(2).

${ }^{42}$ Civil and Commercial Code of Thailand, supra note 12, Section 1150.

43 D. Ricardo Sotomonte Mujica, "partnerships and companies A comparative approach to UK business, organizations", REVIST@e - Mercatoria, Vol.3, N0 2. (2004), p. 7.

${ }^{44}$ Civil Code of France, supra note 10, Article 1857.

${ }^{45}$ Ibid., Article 1858, 


\section{Vi. Distribution of Profits AND Losses}

In Germany, as a matter of principle, partners have to wait until the dissolution of the partnership to demand the statement of accounts and distribution of profits and losses. ${ }^{46}$ However, if the partnership is planned to exist for a prolonged period, the statement of accounts and the distribution of profits can be done at the end of every business year. ${ }^{47}$ Regarding how profit and loss distribution can be made, the German law provides that in a case when the shares in profits and losses of the partners are not stated, then each partner, without regard to the nature and size of his contribution, has an equal share in profit and loss. ${ }^{48}$

In Thailand, the law provides that the share of each partner in the profits or losses is in proportion to his contribution. ${ }^{49}$ If the share of a partner is fixed only as to profits or only as to losses, then the proportion is presumed to be the same for profits and losses. ${ }^{50}$

Pursuant to French law, the share of each partner in the profits and his contribution to the losses are determined in proportion to his share in the capital of the partnership. ${ }^{51}$ However, any stipulation to allocate either the totality of the profit made by the partnership or exoneration of him from all the losses is prohibited. ${ }^{52}$

Pursuant to Ethiopian law concerning the distribution of profits and shares, it is provided that every partner can request the distribution of profits as soon as the management report is approved. ${ }^{53}$ Partners are entitled to share equally in the accrued profits and shall contribute equally to the losses sustained by the partnership. ${ }^{54}$ Regarding the share of distribution, as with German law, unless it is otherwise agreed, distribution has to be made equally, irrespective of a partner's contributions. ${ }^{55}$

\footnotetext{
${ }^{46}$ Civil Code of Germany, supra note 18, Section 721 (1).

47 Ibid., Section 721(2).

48 Ibid., Section 722(1).

49 Civil and Commercial Code of Thailand, supra note 12, Section 1044.

${ }^{50}$ Ibid., Section 1045.

${ }^{51}$ Civil Code of France, supra note 10, Article 1844 (1).

52 Ibid.

53 Commercial Code of Ethiopia, supra note 1, Article 251 (2).

${ }^{54}$ Ibid, Article 252 (1).

${ }^{55}$ Ibid., Article 270 (3).
} 
The unique thing under Ethiopian law is the exemption of skill contributors from sharing losses of the partnership, but their entitlement to take profits. ${ }^{56}$ Regarding the time of distribution, the position taken by Ethiopian law is more logical and fairer than that in Germany. The Ethiopian law adopts mandatory distribution of profits without taking into consideration the protracted nature of the partnership which is very important to maintain the interest of partners and maybe in the long run the partnership itself. The position of Thailand's and France's laws on the distribution of profit and loss is more appropriate, as they prefer distribution based on contribution unlike the case in German and Ethiopian law.

\section{DISSOLUTION}

In all jurisdictions, ordinary/civil code partnership can be dissolved upon expiration of the time for which it had been formed, by the achievement or the extinction of its object, by anticipated dissolution decided by the partners with advance notice, and by anticipated dissolution ordered by the court for good cause. ${ }^{57}$ However, the French ${ }^{58}$ and Thai laws ${ }^{59}$ are different from that of Ethiopia and Germany in that they allow partners to include any further grounds of dissolution in the contract of partnership.

French law differs from the remaining three in that as a rule a partnership cannot be dissolved by the death of a partner and it continues with his heirs or legatees in so far as there is no agreement otherwise. ${ }^{60}$ Under German law, the insolvency of a partner and the partnership itself is recognized as another ground for the dissolution of partnership. ${ }^{61}$

56 Ibid., Article 254.

57 Civil Code of France, supra note 10, Article 1844-7(1),(2),(4) and (5); Civil and Commercial Code of Thailand, Supra Note 12, Section 1055 (2)-(4), Section 1057 and Commercial Code of Ethiopia, supra note 1, Article 258, 217(a), 217(c), 218(1).

58 Civil Code of France, supra note 10, Article 1844-7(8).

59 Civil and Commercial Code of Thailand, supra note 12, Section 1055(1).

${ }^{60}$ Civil Code of France, supra note 10, Article 1870.

${ }^{61}$ Civil Code of Germany, supra note 18, Section 728. 
In this regard, the case in Ethiopia ${ }^{62}$ and Thailand ${ }^{63}$ is slightly different as they recognize only bankruptcy or incapacitation of a partner, not insolvency of the partnership as grounds fordissolution. Unlike the Ethiopian and Thai law, in the French civil code partnership, it is the insolvency of partnership that is recognized as grounds for dissolution of the partnership. ${ }^{64}$

To conclude, the French and Thai laws allow the parties to the partnership to agree to include other grounds of dissolution; whereas, the Ethiopian and German laws specifically list the grounds of dissolution. The approach of the French law regarding the fate of the partnership when one of the partners is dead is more logical and acceptable. It would be illogical and may affect the interest of both the heirs and the partnership itself to dissolve the partnership owing to the death of the partner in the absence of a prior agreement to do so.

\section{EXPULSION OF PARTNER}

Expulsion is the forcible removal of a member from a partnership. Expulsion may not be always fault-based since a member can also be expelled even in the absence of a fault. A member who joins in the formation or after the formation of the partnership is not a permanent member who cannot be expelled, but rather his membership depends upon his conduct, the partnership agreement, and what the law says.

Regarding expulsion/withdrawal of a partner, the French law provides that a partner may withdraw totally or partially from the partnership subject to the conditions provided under the partnership agreement or by authorization given by a unanimous resolution of the other partners or by a judicial decision. ${ }^{65}$ Regarding the fate of the withdrawing partner, the French law provides that he is entitled to reimbursement of the value of his rights in the partnership. ${ }^{66}$ Rather under German law, the expulsion of a partner is possible only if he /she agree to

\footnotetext{
${ }^{62}$ Commercial Code of Ethiopia, supra note 1, Article 260

63 Civil and Commercial Code of Thailand supra note 12, Section 1055 (5).

${ }^{64}$ Civil Code of France, supra note 10, Article 1844-7(7).

${ }^{65}$ Ibid., Article 1869.

${ }^{66}$ Ibid.
} 
the expulsion under the partnership agreement. ${ }^{67}$ In such a case, the partnership will be carried on by the remaining partners and the partner for whom a circumstance occurs which entitles the remaining partners to give notice may be excluded from the partnership. ${ }^{68}$ Under the Thai ordinary partnership law, if a given partner has committed faults that result in the dissolution of the partnership by the court, in such a case, the court may upon the application of the remaining partners, instead of dissolution, order the expulsion of the partner in question. ${ }^{69}$

Regarding the expulsion of a partner, the Ethiopian ordinary partnership law provides that the court may order the expulsion of a partner for good cause and the partnership shall continue as between the remaining partners. ${ }^{70}$ Here, the law fails to provide what amounts to a good cause. Additionally, partners who are given notice of dissolution of partnership can expel that particular partner to prevent the dissolution of the partnership. ${ }^{71}$ However, while they are doing so; they have to pay out their share. ${ }^{72}$ Generally, under all jurisdictions, grounds for the expulsion of a partner are not provided except in Thailand.

The issue related to remedies of unlawful expulsion of a partner is not addressed in any of the partnership regimes which are being compared. However, the Revised Uniform Partnership Act provides that a partner who is wrongfully dissociated from a partnership can claim damages from the other partners for the damage he sustained through the wrongful expulsion. ${ }^{73}$ Taking into account the fact that the personality of members matters, the position taken by the French law and The Revised Uniform Partnership Act is more appropriate as it opens authorization given by a unanimous resolution of the other partners and authorization by the judicial decision as further ways of the expulsion of a partner in addition to the prior agreement of the partners.

\footnotetext{
${ }^{67}$ Civil Code of Germany, supra note 18, Article 737

68 Ibid.

${ }^{69}$ Civil and Commercial Code of Thailand, supra note 12, Section 1058.

${ }^{70}$ Commercial Code of Ethiopia, supra note 1, Article 261.

${ }^{71}$ Ibid., Article 259.

72 Ibid.

${ }^{73}$ Schneeman, supra note 29, p. 91-92.
} 


\section{CONCLUSIONS}

The comparative analysis made in this paper shows that regulation of an ordinary partnership in Ethiopia has more commonalities with that of Thai and French ordinary/civil partnerships. However, it also reveals the areas in which the Ethiopian law has to improve.

The first area is regarding the transfer of shares: Ethiopia has to benefit from the experience of the French law which adopts a liberal approach to the transfer of shares for ascendants and descendants.

The second one that needs improvement is about how the distribution of profits and losses is to be made. In this regard, it would be sound if Ethiopia adopted the approach of France and Thailand which is distribution based on contribution. The third area that needs improvement is the regulation of dissolution of the partnership. France and Thailand allow the parties' partnership agreement to include other grounds of dissolution which should be adopted. Fourth, Ethiopia should also rewrite the provision of the commercial code which deals with the dissolution of partnership because of the death of a partner and should adopt the position of the French law as it leaves it to the parties to determine whether the death of a partner can be a cause for the dissolution of a civil partnership or not. Finally, Ethiopia should also revise the provisions regarding the expulsion of a partner. In this regard, the Ethiopian law should regulate the remedies for the unlawful expulsion of a partner and should come up with listed grounds for the expulsion of a partner. 
